FILOLOGIJA 68, Zagreb 2017.

UDK 811.163.42'374'0

$811.163 .1 ' 374$

https://dx.doi.org/10.21857/94kl4cxrkm

Pregledni članak

Primljen 30.IV.2017.

Anica Nazor

Prihvaćen za tisak 25.IX.2017.

Hrvatska akademija znanosti i umjetnosti

Zrinski trg 11, HR-10000 Zagreb

\title{
O POČETCIMA RADA NA RJEČNIKU CRKVENOSLAVENSKOGA JEZIKA HRVATSKE REDAKCIJE
}

\begin{abstract}
Autorica se osvrće na početke rada na Rječniku crkvenoslavenskoga jezika hrvatske redakcije, započetom koncem 1959. godine u Staroslavenskom institutu u Zagrebu, koji je od svojega utemeljenja (1952. godine) planirao prirediti Rječnik iz hrvatskih glagoljskih starina, jer je na tom jeziku očuvan bogat korpus glagoljskih rukopisa i tiskanih knjiga biblijskoga, liturgijskoga i književnoga sadržaja. Zato je Institut podržao inicijativu pokrenutu na IV. međunarodnom slavističkom kongresu u Moskvi 1958. godine, da se pripremi jedinstveni Rječnik crkvenoslavenskoga jezika svih redakcija, u kojem bi na jednom mjestu bile zastupljene sve redakcije crkvenoslavenskoga jezika.
\end{abstract}

Moskovsku inicijativu iz 1958. godine da se izradi jedinstveni Rječnik crkvenoslavenskoga jezika svih redakcija prihvatio je Staroslavenski institut u Zagrebu već 1959. godine, jer je od svojega utemeljenja (1952.) planirao prirediti Rječnik iz hrvatskih glagoljskih starina. Pokazalo se da bi izrada jedinstvenoga rječnika svih redakcija bio zahtjevan, u praksi gotovo neprovediv zadatak. Stoga je dogovoreno da se pripreme rječnici pojedinih redakcija na zajedničkim načelima.

U vrijeme pripremnih radova na Rječniku crkvenoslavenskoga jezika hrvatske redakcije bilo je mnogo problema - stručnih i kadrovskih, pa i materijalnih. Nije bio objavljen ni jedan biblijski ni liturgijski rukopis. Nije bilo objavljenih potanjih opisa glagoljskih zbornika, pa se nije moglo znati koji su prilozi u njima napisani na crkvenoslavenskom jeziku. Nije bilo ni gramatičkoga opisa hrvatske redakcije crkvenoslavenskoga jezika. U Staroslavenskom je institutu bilo malo suradnika (ni jedan nije imao leksi- 
kografskoga iskustva). Unatoč spomenutim i mnogim drugim teškoćama objavljena su dva sveska Rječnika (od A do ZAPOVÊDNICA) i ocijenjena »kao djelo od najizvrsnijih dostignuća hrvatske filološke, odnosno humanističkih znanosti uopće u zadnjim desetljećima« (Reinhart). U pripremi Rječnika crkvenoslavenskoga jezika hrvatske redakcije pomagali su iskusni suradnici na Slovníku jazyka staroslověnského iz Brna i Praga: Marketa Štěrbová, Josef Kurz, František Václav Mareš, Zoe Hauptová, Zdenka Ribarova, kojima autorica izriče duboku zahvalnost.

Od svojega utemeljenja Staroslavenski je institut u Zagrebu planirao izradu rječnika crkvenoslavenskoga jezika hrvatske redakcije, jer je na tom jeziku očuvan bogat korpus glagoljskih rukopisa i tiskanih knjiga biblijskoga, liturgijskoga i književnoga sadržaja. Od biblijskih tekstova očuvani su glagoljski fragmenti apostola, dva cjelovita psaltira (jedan s komentarom, a cjelovite psaltire sadrže potpuni glagoljski brevijari) i tekstovi u pojedinim glagoljskim zbornicima. Više od biblijskih rukopisa očuvano je liturgijskih knjiga: rukopisnih i tiskanih - misala, brevijara, ponešto i rituala. Očuvano je sedamnaest glagoljskih rukopisnih misala i mnogo fragmenata, četiri tiskana (do 1531. godine), trideset rukopisnih brevijara (i mnogo fragmenata) i tri tiskana (do 1561. godine), te više glagoljskih zbornika s biblijskim te s tekstovima apokrifa i legendi.

Glagoljski misali, još više brevijari, u svom sastavu sadrže obilje biblijskih čitanja pa i cjelovitih biblijskih - starozavjetnih i novozavjetnih knjiga. Stoga je bilo naravno da je Staroslavenski institut planirao prirediti Rječnik iz hrvatskih glagoljskih starina, za koji su bili već ekscerpirani: Misal kneza Novaka iz 1368. godine, prvotisak glagoljskoga Misala iz 1483. godine i tiskani Baromićev brevijar iz 1493. godine. A kad je na IV. međunarodnom slavističkom kongresu u Moskvi 1958. godine pokrenuta inicijativa da se počne s pripremom Rječnika crkvenoslavenskoga jezika svih redakcija, u kojem bi na jednom mjestu bile obuhvaćene sve redakcije crkvenoslavenskoga jezika, Staroslavenski je institut podržao moskovsku inicijativu. Inicijativa je pak pokrenuta $\mathrm{u}$ trenutku kad su se pojavili prvi svesci Slovníka jazyka staroslověnského (Lexicon linguae palaeoslovenicae), magistralnoga leksikografskoga djela, priređena prvi put na iscrpnoj, potpunoj građi iz svih rukopisa za koje se pretpostavlja da su nastali ili da su mogli nastati u najstarijem, ćirilometodskom vremenu. Nije, stoga, slučajno što je upravo iz uredništva spomenutoga Slovníka potekla inicijativa o pripremi rječnika crkvenoslavenskoga jezika svih redakcija kao prirodnoga nastavka njihova rječnika staroslavenskoga jezika.

Slovník jazyka staroslověnského pripremao se u krilu tadašnje Čehoslo- 
vačke akademije znanosti (Českoslovanská akademia věd) koja je u okviru svojega Instituta za slavistiku (Slovanský ústav) za Rječnik osnovala jedinicu pod nazivom Slovník jazyka staroslověnského i to na dvama mjestima: u Pragu i Brnu sa stalnim, kvalificiranim suradnicima, leksikografima, među kojima su bili stručnjaci za grčki i latinski jezik (konkretnije stručnjak za srednjovjekovni latinitet), za ruski i njemački jezik. Slovník je djelo dviju generacija, objavljen u četirima svescima: glavni je urednik prvih dvaju svezaka ugledni paleoslavist Josef Kurz, a treći i četvrti uredila je njegova nasljednica, također ugledna paleoslavistica, Zoe Hauptová, koja je Slovníku poklonila svoja cjeloživotna istraživanja.

Kad je dakle Staroslavenski institut koncem 1959. godine počeo provoditi u djelo moskovsku inicijativu, imao je samo - na prste jedne ruke su se mogli nabrojiti - nekoliko stalnih znanstvenih suradnika, među kojima nije bilo leksikografa s iskustvom. Morao se osloniti uglavnom na honorarne ekscerptore slaviste, kroatiste i klasične filologe.

Dakako, u početku je trebalo odrediti korpus izvora na kojima će se Rječnik izraditi, što je bio osjetljiv zadatak, jer tada nije bio objavljen ni jedan biblijski ni liturgijski rukopis. Potanjih opisa glagoljskih zbornika nije bilo, iz kojih bi se moglo odrediti koji su prilozi u njima napisani na crkvenoslavenskom jeziku. Upravo su zbornici dragocjeni izvori, jer tematski i sadržajno proširuju i obogaćuju biblijski i liturgijski leksički fond.

Na početku se znalo da u temeljne izvore ulaze misalski tekstovi, među kojima je najstariji glagoljski Misal iz 14. stoljeća, poznat kao Omišaljski misal, koji se nalazio u omišaljskoj crkvi na otoku Krku najmanje od god. 1387. do 1627. godine, a danas se čuva u Vatikanskoj knjižnici (Biblioteca Apostolica Vaticana) u fondu Borgiano (Borg. Illir. 4). Stoga je ekscerpiranje moglo početi tim izvorom. Srećom što je tadašnja Sveučilišna knjižnica u Zagrebu posjedovala mikrofilm Misala, na temelju kojega je bilo moguće izraditi fotokopije rukopisa i iz njih obavljati ekscerpiranje.

Kad kažem srećom, mislim na činjenicu da je osnivanje fototekâ, u kojima bi se pohranjivali mikrofilmovi i fotokopije vrijednih pisanih hrvatskih nacionalnih spomenika, počelo intenzivnije nakon Drugoga svjetskoga rata zahvaljujući nastojanjima znanstvenih, napose javnih radnika, među kojima se istakao Ivo Frol, pjesnik, kritičar i slavist. Tada je snimljeno na mikrofilmove više rukopisa iz hrvatskih i inozemnih knjižnica i arhiva. Od glagoljskih rukopisa, a tiču se izvora za hrvatski crkvenoslavenski Rječnik, mikrofilmovani su iz Austrijske nacionalne knjižnice u Beču (Österreichische Nationalbibliothek) Brevijar Vida Omišljanina, Cod. slav. 3; Misal kneza Novaka, Cod. slav. 8, Ročki misal, Cod. slav. 4; Psaltir Petra Fraščića, Cod. slav. 77; i iz Vatikanske knjižnice snimljen je spomenuti najsta- 
riji glagoljski Misal Borg. Illir $4 .^{1}$

Danas, nakon objavljenih dvadeset sveščića Rječnika crkvenoslavenskoga jezika hrvatske redakcije, ukoričenih u dvama svescima velikoga formata (30 $\mathrm{cm})$ s obrađenim riječima A do riječi ZAPOVÊDNICA po glagoljskoj azbuci, zna se da je korpus Rječnika sastavljen od šezdesetak izvora. Obuhvatio je sve fragmente do kraja 13. stoljeća (apostola, misala, brevijara, homilija, apokrifa i legendi), najpotpunije (i najstarije) rukopise misala, brevijara, rituala, psaltira i dijelove (priloge) pojedinih zbornika (popis izvora objavljen je u prvom sveščiću Rječnika). Odreda su ekscerpirani iz fotokopija originala. Ekscerpirana je građa kolacionirana $s$ fotokopija originala. ${ }^{2}$

Ekcerpiranje je metodološki naslonjeno na ekscerpiranje za Slovník jazyka staroslověnského. Pri određivanju sadržaja rječničke kartice, tj. podataka koje na karticu treba unijeti, poslužila su objavljena načela Slovníka, pismeni kontakti s uredništvom Slovníka, napose s glavnim urednikom Josefom Kurzom. ${ }^{3}$ Glavni urednik prof. Josef Kurz i njegova nasljednica Zoe Hauptová osobno su posjećivali Staroslavenski institut, a Zoe Hauptová u njemu je povremeno i radila.

Već se u početku, nakon iscrpnih diskusija na prvom sastanku Međunarodne komisije za Rječnik crkvenoslavenskoga jezika, održanom 1963. god. u Staroslavenskom institutu uoči V. međunarodnoga slavističkog kongresa u Sofiji, vidjelo da se zamisao o jedinstvenom Rječniku svih redakcija crkvenoslavenskoga jezika mora otkloniti (odgoditi). Prihvaćen je prijedlog Vjekoslava Štefanića da se izrade rječnici pojedinih redakcija na zajedničkim načelima. "Sasvim je svejedno hoćemo li sve redakcije staviti u jednu knjigu ili će svaka redakcija imati svoju knjigu«. Jedinstveni rječnik može se prirediti kad budu priređeni rječnici ostalih redakcija. (Štefanić).

Imajući na umu jedinstveni Rječnik, makar u neizvjesnoj budućnosti, u

\footnotetext{
${ }^{1} \mathrm{~S}$ fotokopiranjem izvora za Rječnik utemeljena je u Staroslavenskom institutu fototeka glagoljskih rukopisa i rijetkih primjeraka glagoljskih tiskanih knjiga: od 1959. godine u njoj su se našli fotokopirani svi glagoljski rukopisi, koji su bili mikrofilmovani za Arhiv tadašnje Jugoslavenske (danas Hrvatske) akademije znanosti i umjetnosti, Sveučilišne knjižnice i još nekih knjižnica. S fotokopiranjem glagoljskih rukopisa i primjeraka glagoljskih inkunabula, ponajprije onih koji se čuvaju izvan Hrvatske, Staroslavenski je institut nastavio i za to izdvojio pozamašna sredstva, iako ih za tu svrhu nije mogao dobiti niotkud. Pomogao je sam, izvrstan fotograf Sveučilišne knjižnice, Ivan Pančoka. Fotokopije je za Staroslavenski institut izrađivao po znatno nižoj cijeni, na čemu smo mu zahvalni i danas, mnogo godina nakon njegova odlaska u vječnost.

${ }^{2}$ Glavni dio građe kolacionirala je Nevenka Linarić (†1976.).

${ }^{3}$ Potanje o potrebi pripreme rječnika crkvenoslavenskoga jezika, oblikovanju i sadržaju natuknice te popis izvora obrazloženo je u prvom sveščiću Rječnika crkvenoslavenskoga jezika hrvatske redakcije, str. I-XLVIII.
} 
Staroslavenskom se institutu sva ekscerpirana građa umnožila u dva primjerka. Pohranjena je u katalogu riječi poredanih azbučnim redom (azbučni katalog) i katalogom po izvorima (mjesni katalog). Umnožavalo se ručno jednostavnom, da ne kažem primitivnom, tehnikom: na stroju, koji je iz Beča pribavio prof. Josip Hamm (†1986.). On je od 1960. godine radio na Bečkom sveučilištu, ali je do kraja života bdio nad Rječnikom i pomagao Staroslavenski institut, koji je utemeljio zajedno s mons. Svetozarom Ritigom i prof. Vjekoslavom Štefanićem. Stroj je radio na špirit i tintu, jer u doba ekscerpiranja nije bilo ni »fotokopera« ni digitalne tehnologije.

U početku se raspravljalo o nazivu jezika. Na spomenutom sastanku Međunarodne komisije za Rječnik u Zagrebu inicijatori Rječnika Bohuslav Havránek i Josef Kurz predložili su umjesto crkvenoslavenskoga naziv općeslavenski književni jezik s obrazloženjem da je od 12. -15. stoljeća (negdje i duže) imao ulogu općeslavenskoga jezika. Već je u pozdravnom govoru B. Havránek rekao:

»Rad na Rječniku crkvenoslavenskoga jezika vrlo je aktualan zbog znanstvenih razloga, jer je taj jezik imao veliko značenje u razvitku svih slavenskih jezika. Zato treba da se i zove općeslavenski književni jezik. Njegova je specifičnost što je odmah, od samoga početka bio književni jezik. A rijetki su jezici to bili.«

Josef Kurz smatra da taj jezik nije bio samo crkveni i da je on jedinstven bez obzira na to što postoje redakcije. Za naziv općeslavenski književni jezik osjećalo se da razloge treba tražiti ponajprije u tadašnjim političkim prilikama. U slavenskim zemljama crkveno u to doba u najmanju ruku nije bilo poželjno, pa je jezik trebalo "zaštititi” »zbog šire javnosti, a i zbog vlasti« - govorio je Petar Đorđić. Bio je predložen naziv međuslavenski ili međunarodni slavenski književni jezik. Ipak, zadržan je tradicionalni naziv crkvenoslavenski. Tako je dogovoreno na sastanku Međunarodne komisije za Rječnik u Moskvi koncem travnja 1966. godine.

Vrijeme je prolazilo, a moskovska inicijativa o rječniku crkvenoslavenskoga jezika svih redakcija nije imala stvarnoga odjeka. Zato je Staroslavenski institut pokušao na rad potaknuti slavistička središta u Jugoslaviji, u kojoj je djelovao kao samostalna znanstvena institucija Republike Hrvatske. U institutskim prostorima u Zagrebu je 10. srpnja 1961. godine održan sastanak na kojem su uz domaćine Vjekoslava Štefanića, Josipa Hamma i Nevenku Linarić sudjelovali Petar Đorđić, prof. Filozofskog fakultetea u Novom Sadu i Blaže Koneski, prof. Filozofskog fakulteta u Skoplju. Zaključeno je:

»1. da je potrebno bez odlaganja pristupiti zajedničkom radu na izradbi rječnika koji bi sadržavao nijanse južnoslavenskih redakcija crkvenoslaven- 
skoga jezika iz razdoblja od XI. do kraja XV. stoljeća; 2. da taj rad treba organizirati na saveznoj osnovi, tako da se radi ne samo u Zagrebu, nego i u Skoplju i u Novom Sadu, odnosno u Beogradu; da centar rada treba da ostane u Staroslavenskom institutu u Zagrebu s kojim bi radne jedinice iz ostalih središta bile u stalnom kontaktu; 4) da se u skladu sa saveznim karakterom posla čitav rad treba da dotira iz sredstava Saveznog fonda za naučni rad; 5) da se predloži Jugoslavenskom slavističkom komitetu da na svojem sastanku u Ljubljani [tj. za vrijeme skoroga kongresa, o.p. A. N.] a) izabere stalna komisija za Rječnik iz književnih starina hrvatskih, srpskih i makedonskih u koju bi ušli predstavnici Skoplja, Beograda - Novog Sada i Zagreba, b) da komisiji dade mogućnost da se odmah konstituira i izaberu članovi svojih radnih jedinica i da rasporedi rad, c) da o tome obavijesti Međunarodni slavistički komitet u Sofiji i d) da poduzme sve što je potrebno da se za rad komisije osiguraju sredstva iz Saveznog savjeta i Saveznoga fonda za naučni rad. ${ }^{4}$

Staroslavenskom je institutu dan zadatak da o tome obavijesti Jugoslavenski slavistički komitet.

U duhu spomenutih zaključaka o pitanju redakcijskih rječnika crkvenoslavenskoga jezika govorio je Vjekoslav Stefanić na jugoslavenskom slavističkom kongresu u Ljubljani 21. rujna 1961. godine. ${ }^{5}$ Govor je bio poticajan: u glavnim jugoslavenskim slavističkim središtima počeo je rad na rječnicima - negdje prije, negdje kasnije: u Skoplju 1964., u Beogradu i Sarajevu 1969. godine. Uspjela su se namaknuti savezna materijalna sredstva, do kojih se moglo doći ispunjavanjem brojnih "papira" i prilaganjem brojnih dokumenata. ${ }^{6}$ Savezna su sredstva bila izdašnija od republičkih, ali su jednokratno trajala - četiri godine, jer se savezni fond ugasio.

Do danas su, kao što je spomenuto, objavljena dva sveska Rječnika crkvenoslavenskoga jezika hrvatske redakcije (slova A do ZAPOVÊDNICA); sveska Rječnika makedonske redakcije i ogledni svezak Sprskoslovenskoga rečnika jevanđelja u Beogradu (sastavio Viktor Savić, uredila Gordana Jovanović).

Završavajući osvrt o početcima rada na Rječniku crkvenoslavenskoga jezika hrvatske redakcije, moram priznati da smo obradu riječi dočekali sa strepnjom. Nismo, naime, bili sigurni hoćemo li kvalitetom moći dosegnuti kvalitet svojega uzora: Slovníka jazyka staroslověnského, čemu smo težili. Trebalo je uspostaviti neutralan ("idealan") redakcijski lik natuknice kad u

\footnotetext{
${ }^{4}$ Slovo 11-12 (1962), 186.

${ }^{5}$ Tekst je objavljen u Slovu 11-12 (1962), 181-187: Vjekoslav Štefanić, Problem Rječnika južnoslavenskih redakcija staroslavenskog jezika.

${ }^{6}$ Zorno je to predočila službenica Staroslavenskoga instituta Marija Beroš slikovitom rečenicom: »Ne bih više umnažala papire na kilograme nego na "frtalj kile"«. Umnažala je ručno na špirit i tintu.
} 
tekstovima (vrelima) nije bio potvrđen. Za sklonidbene riječi (imenice, pridjeve, zamjenice, brojeve) taj je lik u načelu nominativ singulara, a za glagole infinitiv. Složen zadatak, jer tada nije bilo gramatičkoga opisa crkvenoslavenskoga jezika hrvatske redakcije, dakle nije bilo gramatike hrvatskoga crkvenoslavenskoga jezika. Kadrova koji su obradu mogli obavljati, napokon, i koji su to htjeli zbog neadekvatnoga vrednovanja, bilo je malo. $\mathrm{K}$ tomu gotovo u samom početku obrade rječničke građe Staroslavenski je institut izgubio dvoje nenadoknadivih, kvalificiranih suradnika na Rječni$k u$, prerano preminulih 1986. godine: klasičnu filologinju Biserku Grabar (r. 1932.), teologa, trećoredca (glagoljaša) i slavista Josipa Leonarda Tandarića (r. 1935.). Srećom: opet su pomogli suradnici iz praškoga Slovníka: prihvatili su (glavno) uredništvo, najprije František Václav Mareš (†1994.), Zoe Hauptová, nakon njezine smrti (†2012.) Zdenka Ribarova.

Da današnji svesci Rječnika crkvenoslavenskoga jezika hrvatske redakcije ugledaju "svjetlo dana” zaslužne su ponajprije dvije institutske suradnice: Ivana Mulc i Marija Klenovar. One su sudjelovale u svim fazama rada na Rječniku: ekscerpiranju, obradi, uređivanju i redigiranju građe. Obavljale su poslove tajnice (Marija Klenovar ih i danas obavlja). Sav radni vijek u Staroslavenskom institutu (i nakon odlaska u mirovinu), znanje, iskustvo i privrženost poklonile su Rječniku: Rječnik hrvatskoga crkvenoslavenskog jezika i grafički slijedi Slovník jazyka staroslověnského ${ }^{7}$. Rješenje je osmislila Vjera Lopina, koja je na računalu složila i prelomila prvih četrnaest sveščića. Zajedno s Franom Parom dizajnirala je ćirilska slova za natuknicu, a sama je dizajnirala grčka slova. ${ }^{8}$ Za glagoljska slova što ih je dizajnirao grafički umjetnik Frane Paro, jednom je prilikom František Václav Mareš rekao da su u sebi uspjela objediniti slova svih hrvatskoglagoljskih rukopisa.

Unatoč nemalim teškoćama, koje ga prate od početka, Rječnik crkvenoslavenskoga jezika hrvatske redakcije izlazi. U znanstvenoj je javnosti dobio pozitivne ocjene, kao djelo od »najizvrsnijih dostignuća hrvatske filološke, odnosno humanističkih znanosti uopće u zadnjim desetljećima. «9 Sastavljači pak prve gramatike hrvatskoga crkvenoslavenskog jezika napisali su:

»Bez kartotečne građe prikupljene i sastavljene za izradu Rječnika [ tj. hrvatskoga crkvenoslavenskoga jezika, op. A. N.] i fototeke [tj. institutske, op. A. N.] koja sadrži kopije gotovo svih glagoljskih kodeksa koji su razasuti po knjižnicama i zbirkama širom svijeta izrada ove gramatike ne bi bila

\footnotetext{
${ }^{7}$ Izlazi u velikom formatu $(30 \mathrm{~cm})$. Tekst se slaže na računalu u dvama stupcima, na više pisama (glagoljica, ćirilica, latinica, grčki alfabet) i jezika (crkvenoslavenski, hrvatski, engleski, grčki, latinski).

${ }^{8}$ U daljnjem sveščićima grčka je slova redizajnirao Jozo Vela.

${ }^{9}$ Ocijenio je Johannes Reinhart u recenziji rukopisa 20. sveščića Rječnika.
} 
moguća. ${ }^{10}$

Stručne ocjene dovoljan su motiv da se započeto djelo i dovrši. To će, nema sumnje, učiniti poletna druga generacija suradnika u Staroslavenskom institutu na čelu s mladim i kvalificiranim Jozom Velom.

\section{Literatura}

Grković-Mejdžor. 2007. Rječnik crkvenoslavenskoga jezika hrvatske redakcije. 1. svezak (A - VRÊDb). Prilozi za književnost, jezik, istoriju i folklor (2006), knj. LXXII. , sv. 1-4, Beograd, 2007, 185-187 (rec.)

Holzer, Georg. 1996. Rječnik crkvenoslavenskoga jezika hrvatske redakcije. Lexicon linguae slavonicae redactionis croaticae. Zagreb (Staroslavenski zavod Hrvatskoga filološkoga instituta) 1991. Wiener slavistisches Jahrbuch 42, 318. (rec.)

Klenovar, Marija. 1990. Morfološka funkcija prefiksa vbz-/vbs- u hrvatskoj redakciji crkvenoslavenskog jezika. Suvremena lingvistika 29-30, Zagreb, $41-49$.

Mareš, František Václav. 1962-1966. Návrh připravaných prací pro slovník jazyka církvevněslovanského. Prag 1962., 27 str.; Prag 1966., 26 str.

Moszyński, Leszek. 1991. Rječnik crkvenoslavenskoga jezika hrvatske redakcije 1. Uvod, Zagreb 1991, s. XLVIII; 2. A - Antiohiiskь, Zagreb 1992., s. 64, Rocznik slawistyczny 50, 136-146. (rec.).

Moszyński, Leszek. 1966. Otnošenie slovarja cerkovnoslavjanskogo jazyka k slovarjam otdel'nyh slavjanskih jazykov. Voprosy jazykoznaniya 5, 8185.

Nazor, Anica. 1963. Jezični kriteriji pri određivanju donje granice crkvenoslavenskog jezika u hrvatskoglagoljskim tekstovima. (Prilog diskusiji o problemima crkvenoslavenskog thesaurusa). Slovo 13, 68-86.

Nazor, Anica. 1966. O slovare horvatsko-glagoličeskoj redakcii obščeslavjanskogo literaturnogo (cerkovnoslavjanskogo) jazyka. Voprosy jazykoznanija 5, 99-105.

Nazor, Anica. 1968. Praca nad Slownikiem języka cerkiewno-słowiańskiego redakcji chorwackiej w Instytucie Staroslowiańskim im. Svetozara Ritiga w Zagrzebiu. U: Sympozjum leksikograficzne w Krakowie 3-5 kwietnia 1967 r. PAN, Kraków. 176-179.

Nazor, Anica. 2008. Rječnik crkvenoslavenskoga jezika iniciran na IV. međunarodnom slavističkom kongresu u Moskvi 1958. godine. U: Vidjeti Ohrid. Referati hrvatskih sudionica $i$ sudionika za XIV. međunarodni sla-

10 Sofija Gadžijeva, Ana Kovačević, Milan Mihaljević, Sandra Požar, Johannes Reinhart, Marinka Šimić, Jasna Vince: Hrvatski crkvenoslavenski jezik, Hrvatska sveučilišna naklada - Staroslavenski institut, Zagreb 2014., 8. 
vistički kongres. (Ohrid 10.-16. rujna 2008.) Zagreb: Hrvatsko filološko društvo - Hrvatska sveučilišna naklada, Zagreb, 65-82.

Rodić, Nikola. 1995. Prvi redakcijski rečnik crkvenoslovenskoga jezika. Rječnik crkvenoslavenskoga jezika hrvatske redakcije 1(1991), 2(1992), 3(1993). Staroslavenski zavod Hrvatskoga filološkoga instituta, Zagreb. Južnoslovenski filolog 51(1995), 363-367 (rec.).

\title{
On the beginnings of the Dictionary of the Croatian redaction of Church Slavonic compiling
}

\begin{abstract}
The Moscow initiative (1958) for editing a dictionary of all redactions of Church Slavonic was accepted by the Old Church Slavonic Institute due to the fact that from its establishment (1952) the Institute planned to edit Rječnik iz hrvatskih glagoljskih starina. However, editing such a unique dictionary of all redactions turned out to be practically impossible to conduct. Therefore, it was arranged that dictionaries of the different redactions should be compiled, but on the common principles.

There had been many difficulties - professional as well as ones involving human resources and financial sources - during the preparation period for compiling the Dictionary of the Croatian redaction of Church Slavonic. None of the biblical or liturgical glagolitic manuscript had been published. The same goes for the detailed descriptions of the glagolitic miscellanies. Consequently, it was unknown which texts in them are written in Church Slavonic. Also, there was no grammatical description of the Croatian redaction of Church Slavonic. At the time, there were not many associates in the Old Church Slavonic Institute and none of them had any lexicographical experience. Despite mentioned and many other difficulties two volumes of the Dictionary had been published ( $a-$ zapovêdnica) so far and evaluated as »one of the most excellent achievements of the Croatian humaniteies, i. e. philology in the last decades « (Reinhart). In the preparation of the Dictionary of the Croatian redaction of Church Slavonic many experienced associtates of the Slovník jazyka staroslověnského from Brno and Prague helped: Marketa Štěrbová, Josef Kurz, František Václav Mareš, Zoe Hauptová and Zdenka Ribarova, to whom the author expresses gratitude.
\end{abstract}

Ključne riječi: Rječnik crkvenoslavenskoga jezika hrvatske redakcije

Key words: Dictionary of the Croatian redaction of Church Slavonic 
